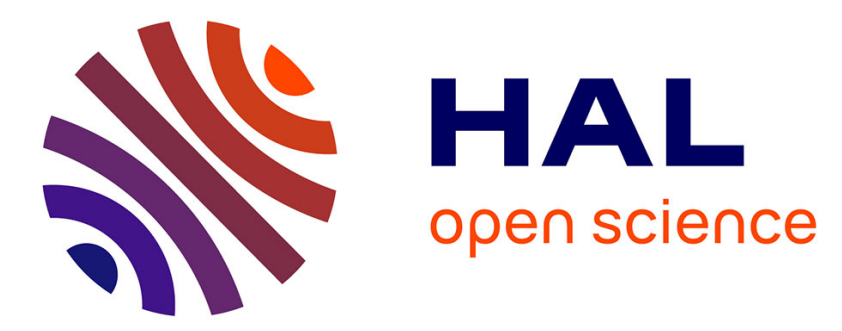

\title{
Biotransformation of nitriles to amides using soluble and immobilized nitrile hydratase from Rhodococcus erythropolis A4
}

\author{
David Kubac, Ondrej Kaplan, Veronika Elisakova, Miroslav Patek, Vojtech \\ Vejvoda, Kristyna Slamova, Andrea Tothova, Marielle Lemaire, Estelle \\ Gallienne, Sabine Lutz-Wahl, et al.
}

\section{To cite this version:}

David Kubac, Ondrej Kaplan, Veronika Elisakova, Miroslav Patek, Vojtech Vejvoda, et al.. Biotransformation of nitriles to amides using soluble and immobilized nitrile hydratase from Rhodococcus erythropolis A4. Journal of Molecular Catalysis B: Enzymatic, 2008, 50, pp.107-113. hal-00204397

\section{HAL Id: hal-00204397 https://hal.science/hal-00204397}

Submitted on 14 Jan 2008

HAL is a multi-disciplinary open access archive for the deposit and dissemination of scientific research documents, whether they are published or not. The documents may come from teaching and research institutions in France or abroad, or from public or private research centers.
L'archive ouverte pluridisciplinaire HAL, est destinée au dépôt et à la diffusion de documents scientifiques de niveau recherche, publiés ou non, émanant des établissements d'enseignement et de recherche français ou étrangers, des laboratoires publics ou privés. 


\title{
Biotransformation of nitriles to amides using soluble and immobilized nitrile hydratase from Rhodococcus erythropolis A4
}

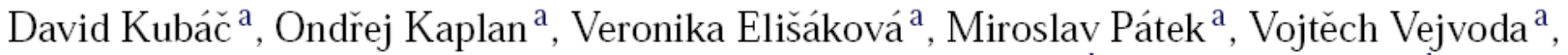 \\ Kristýna Slámováa ${ }^{a}$, Andrea Tóthováa ${ }^{\text {, Marielle Lemaire }}{ }^{\mathrm{b}}$, Estelle Gallienne ${ }^{\mathrm{b}}$, \\ Sabine Lutz-Wahl ${ }^{\mathrm{c}}$, Lutz Fischer ${ }^{\mathrm{c}}$, Marek Kuzma ${ }^{\mathrm{a}}$, Helena Pelantováa ${ }^{\mathrm{a}}$, \\ Sander van Pelt ${ }^{d}$, Jean Bolte ${ }^{\mathrm{b}}$, Vladimír Křen ${ }^{\mathrm{a}}$, Ludmila Martínková ${ }^{\mathrm{a}, *}$ \\ a Institute of Microbiology, Academy of Sciences of the Czech Republic, CZ-142 20 Prague 4, Czech Republic \\ ${ }^{\mathrm{b}}$ University of Blaise Pascal, SEESIB, F-63 177 Aubière Cedex, France \\ ${ }^{\mathrm{c}}$ University of Hohenheim, Institute of Food Science and Biotechnology, Department of Biotechnology, D-70599 Stuttgart, Germany \\ ${ }^{\mathrm{d}}$ Laboratory of Biocatalysis and Organic Chemistry, Delft University of Technology, NL-2628 BL Delft, The Netherlands
}

\begin{abstract}
A semi-purified nitrile hydratase from Rhodococcus erythropolis A4 was applied to biotransformations of 3-oxonitriles 1a-4a, 3-hydroxy-2methylenenitriles 5a-7a, 4-hydroxy-2-methylenenitriles 8a-9a, 3-hydroxynitriles 10a-12a and 3-acyloxynitrile 13a into amides 1b-13b. Crosslinked enzyme aggregates (CLEAs) with nitrile hydratase and amidase activities ( $88 \%$ and $77 \%$ of the initial activities, respectively) were prepared from cell-free extract of this microorganism and used for nitrile hydration in presence of ammonium sulfate, which selectively inhibited amidase activity. The genes nhal and nha2 coding for $\alpha$ and $\beta$ subunits of nitrile hydratase were cloned and sequenced.
\end{abstract}

Keywords: Rhodococcus erythropolis; Nitrile hydratase; Amidase; Branched and substituted nitriles; Cross-linked enzyme aggregates

\section{Introduction}

Bacterial cells with nitrile hydratase activity have been widely used to produce amides from nitriles [1]. However, whole cells usually transform the amides further into carboxylic acids and ammonia by amidases, which are expressed along with nitrile hydratases from the same operon. In this way, the yield and purity of the amide are deteriorated. Therefore, a search for selective amidase inhibitors was performed and dimethylsulfoxide and molecular iodine were shown to assist the preferential action of the nitrile hydratase [2]. Diethylphosphoramidate was also proposed as a selective amidase inhibitor [3] and used for the synthesis of 3-oxoamides from the corresponding nitriles by Rhodococcus rhodochrous whole cells [4]. Alternatively, it is possible to control the enzyme activities by reaction conditions, as demonstrated for nitrile hydratase/amidase enzyme system in Microbacterium imperiale [5].

\footnotetext{
* Corresponding author.

E-mail address: martinko@biomed.cas.cz (L. Martínková).
}

The use of purified or partially purified nitrile hydratases appears to be another solution to this problem. However, this approach was hampered by instability of the enzymes and, until recently, their inavailability on the market. In the present work we demonstrated utility of a semi-purified nitrile hydratase from Rhodococcus erythropolis A4 (formerly Rhodococcus equi A4) [6] for amide production from branched and substituted nitriles. As a cheaper and less laborious alternative, a cell-free extract was used, in which the amide hydrolysis was slowed down by ammonium sulfate, which was previously reported as an efficient inhibitor of the amidase in strain A4 [7]. In order to simplify handling of the nitrile hydratase and to improve its stability, we searched for a suitable immobilization method. Recently, an innovative immobilization technique, which resided in precipitation of the enzyme by different additives like salts or organic solvents and cross-linking of the resulting physical aggregates with glutaraldehyde (CLEAs) [8], was successfully applied to a number of different enzymes [9]. A modification of this method using a milder cross-linking agent, dextran polyaldehyde, was also suitable for the immobilization of relatively labile enzymes like nitrilases [10]. Therefore, we examined the suitability of 
this method for immobilization of the nitrile hydratase from $R$. erythropolis A4.

\section{Experimental}

\subsection{Chemicals}

3-Oxo-3-phenylpropanenitrile (1a), 3-(3-chlorophenyl)-3oxopropanenitrile (2a) and 3-(4-chlorophenyl)-3-oxopropanenitrile (3a) were purchased from Avocado and 4,4-dimethyl-3-oxopentanenitrile (4a) from Aldrich. $(R, S)$-2-(1-Hydroxyethyl)propenenitrile (5a), (R,S)-2-(1-hydroxybutyl)propenenitrile (6a), $(R, S)$-2-( $\alpha$-hydroxybenzyl)propenenitrile (7a), $(R, S)$-4-hydroxy-2-methylenehex-5-enenitrile $(\mathbf{8 a})$ and $(R, S)$ 2-(2-hydroxy-3,3-dimethoxypropyl)propenenitrile (9a) were prepared according to literature procedures [11-13]. $(R, S)$ 3-Hydroxy-3-phenylpropanenitrile (10a) and $(R, S)$-3-hydroxy4,4-dimethylpentanenitrile (11a) were obtained by conventional $\mathrm{NaBH}_{4}$-reduction of $\mathbf{1 a}$ and $\mathbf{4 a}$, respectively. $(R, S)-3-(2-$ Furyl)-3-hydroxypropanenitrile (12a) was obtained by $\mathrm{NaBH}_{4}$ reduction of 3-(2-furyl)-3-oxopropanenitrile, which, in turn, was prepared by an adaptation of a published method [14]. Briefly, acetonitrile was reacted with sodium amide in diethyl ether at $-30^{\circ} \mathrm{C}$ and then with ethyl 2-furoate (Aldrich) under the same conditions until the ester disappeared. $(R, S)$-3-(Benzoyloxy)hexanenitrile 13a was prepared via an intermediate (3-hydroxyhexanenitrile), which was synthesized in an analogous way as 12a (from sodium amide and ethyl butyrate), followed by overnight reaction with 3 equiv. of benzoyl chloride in the presence of 1.3 equiv. of pyridine and catalytic amounts of 4-dimethylaminopyridine in dichloromethane at $0^{\circ} \mathrm{C}$ to room temperature. Dextran polyaldehyde was prepared by oxidation of dextran as described previously [10].

\subsection{Microorganism and cultivation}

R. erythropolis A4 (formerly denoted as R. equi according to biochemical tests, re-classified according to $16 \mathrm{~S}$ rDNA sequencing [15]; deposited in the Culture Collection of Microorganisms, Masaryk University, Brno, Czech Republic) was grown in 500$\mathrm{mL}$ flasks with $100 \mathrm{~mL}$ of mineral medium [16] supplemented with yeast extract $(3 \mathrm{~g} / \mathrm{L})$ and acetonitrile $(15 \mathrm{mM})$. The cultivation proceeded at shaking ( $200 \mathrm{rpm})$ and $28^{\circ} \mathrm{C}$ for 2 days.

\subsection{Preparation of cell-free extract}

Whole cells of $R$. erythropolis A4 were disintegrated by milling with glass beads as described previously [7].

\subsection{Enzyme purification}

Semi-purified nitrile hydratase from $R$. erythropolis A4 was prepared as described previously [6] and stored at $-80^{\circ} \mathrm{C}$ in Tris/ $\mathrm{HCl}$ buffer $(50 \mathrm{mM}, \mathrm{pH} 7.5)$ containing approximately $0.5 \mathrm{M}$ ammonium sulfate.

\subsection{Immobilization in cross-linked enzyme aggregates}

Precipitant screening was performed as described previously [9]. Briefly, $0.010 \mathrm{~mL}$ of enzyme solution (approximately $0.1 \mathrm{U}$ ) was added to $0.090 \mathrm{~mL}$ precipitant $-70 \%$ saturated solution of ammonium sulfate, tert-butyl alcohol, acetone, acetonitrile, ethyl lactate or polyethylene glycol (relative molecular weight 1305-1595) - and after $15 \mathrm{~min}$ at room temperature the precipitate was redissolved in $0.9 \mathrm{~mL}$ of Tris/ $\mathrm{HCl}$ buffer $(50 \mathrm{mM}$, $\mathrm{pH} 8$ ). Nitrile hydratase activities were assayed as described below. For the production of CLEAs, $20 \mathrm{~mL}$ of cell-free extract (approximately $45 \mathrm{mg}$ of protein) was added to $47 \mathrm{~mL}$ of saturated ammonium sulfate (with $1 \mathrm{mM}$ EDTA, $\mathrm{pH}$ 8.0). Dextran polyaldehyde ( $3 \%$ solution, $4 \mathrm{~mL}$ ) was added and the mixture was stirred for $45 \mathrm{~min}$ at $4{ }^{\circ} \mathrm{C}$. After centrifugation, CLEAs were treated with $0.2 \%$ sodium borohydride dissolved in saturated sodium bicarbonate, centrifuged again, washed three times with Tris/ $\mathrm{HCl}$ buffer $(50 \mathrm{mM}, \mathrm{pH} 8)$ and stored at $4{ }^{\circ} \mathrm{C}$.

\subsection{Activity assay}

The nitrile hydratase was assayed in a reaction mixture $(0.5 \mathrm{~mL})$ containing $25 \mathrm{mM}$ benzonitrile, Tris/ $\mathrm{HCl}$ buffer $(50 \mathrm{mM}, \mathrm{pH} 8)$ and an appropriate amount of the soluble enzyme or CLEAs (approximately $0.25 \mathrm{U}$ ). The reaction proceeded for $10 \mathrm{~min}$ at $30^{\circ} \mathrm{C}$ with shaking in Thermomixer Comfort Eppendorf $(850 \mathrm{rpm})$ and was stopped with $0.1 \mathrm{~mL}$ of $1 \mathrm{M} \mathrm{HCl}$. After centrifugation of the precipitated protein, benzonitrile, benzamide and benzoic acid were determined by HPLC (see below).

\subsection{General procedure for biotransformations}

The reactions proceeded at $28^{\circ} \mathrm{C}$ with shaking in $\mathrm{Na} / \mathrm{K}$ phosphate buffer $(50 \mathrm{mM}, \mathrm{pH}$ 8) containing $2.5-25 \mathrm{mM}$ substrate, methanol $(2-5 \%, v / v)$ as cosolvent and an appropriate amount of the semi-purified enzyme (see Tables 1-3). Alternatively, the reactions were catalyzed by CLEAs (see Table 4) in absence or presence of ammonium sulfate $(360-800 \mathrm{mM})$ and 2 mMEDTA. The reactions were monitored by analytical HPLC (see below).

\subsection{Determination of nitrile hydratase stability}

Cell-free extract or CLEAs were incubated in $50 \mathrm{mM}$ Tris/ $\mathrm{HCl}$ buffer, $\mathrm{pH} 8$, at $28^{\circ} \mathrm{C}$ with shaking in Thermomixer Comfort Eppendorf ( $850 \mathrm{rpm})$. At intervals, samples were withdrawn and assayed for nitrile hydratase activity as described above.

\subsection{HPLC analysis}

Nitriles and biotransformation products were determined by reversed-phase HPLC with a Nova-Pak $\mathrm{C}_{18}$ column $(5 \mu \mathrm{m}, 3.9 \mathrm{~mm} \times 150 \mathrm{~mm})$ and mobile phase consisting of $10 \%$ acetonitrile (compounds $\mathbf{5 a - 6 a , ~ 8 a - 1 2 a}$ and their products), 25\% acetonitrile (compounds $\mathbf{1 a - 4 a}, 7 \mathbf{a}$ and their products), $30 \%$ acetonitrile (benzonitrile and its products) or $40 \%$ acetonitrile (compounds 13a, 13b) and $0.1 \%$ phos- 
Table 1

Hydration of 3-oxonitriles catalyzed by the semi-purified nitrile hydratase<smiles>[R]C(=O)CC#N</smiles>

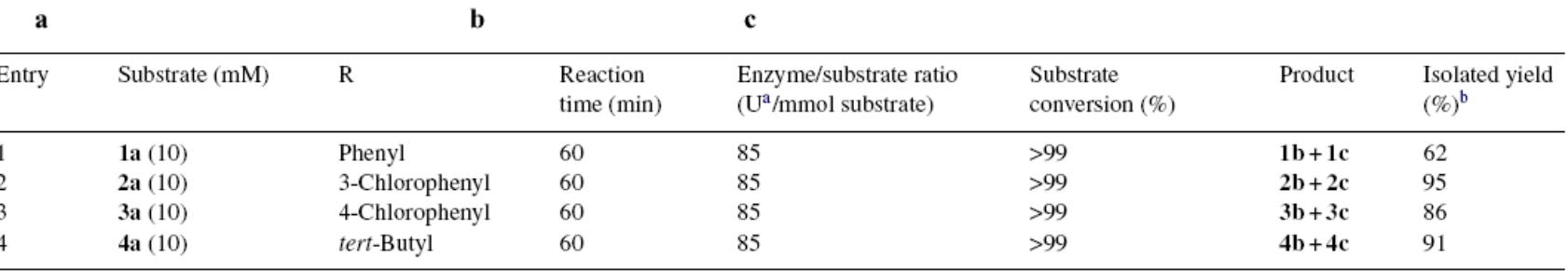

a Activity determined with benzonitrile $(25 \mathrm{mM})$ as substrate.

b On 20-30 mg scale.

Table 2

Hydration of 3- and 4-hydroxy-2-methylenenitriles catalyzed by the semi-purified nitrile hydratase

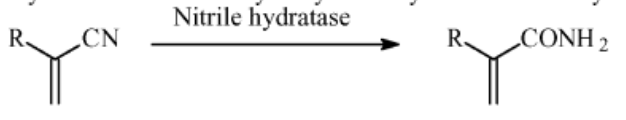

\begin{tabular}{|c|c|c|c|c|c|c|c|}
\hline Entry & Substrate $(\mathrm{mM})$ & $\mathrm{R}$ & $\begin{array}{l}\text { Reaction } \\
\text { time (min) }\end{array}$ & 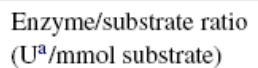 & $\begin{array}{l}\text { Substrate conversion } \\
(\%)\end{array}$ & Product & $\begin{array}{l}\text { Isolated yield } \\
(\%)^{\mathrm{b}}\end{array}$ \\
\hline 5 & 5a (25) & & 30 & 6 & $>99$ & $5 b$ & 82 \\
\hline 6 & $6 a(25)$ & & 120 & 10 & $>99$ & $6 b$ & 79 \\
\hline 7 & $7 a(25)$ & & 180 & 10 & $>99$ & $7 b$ & 69 \\
\hline 8 & $8 \mathrm{a}(25)$ & & 60 & 6 & $>99$ & $8 b$ & 67 \\
\hline 9 & $9 \mathbf{a}(2.5)$ & & 1200 & 20 & 74 & $9 b$ & $27^{\mathrm{c}}$ \\
\hline
\end{tabular}

a Activity determined with benzonitrile $(25 \mathrm{mM})$ as substrate.

${ }^{\mathrm{b}}$ On scale of $25 \mathrm{mg}$ (10a) or approximately $70 \mathrm{mg}$ (other compounds).

${ }^{\mathrm{c}}$ Purified by preparative HPLC.

Table 3

Hydration of 3-hydroxynitriles and 3-acyloxynitrile catalyzed by the semi-purified nitrile hydratase

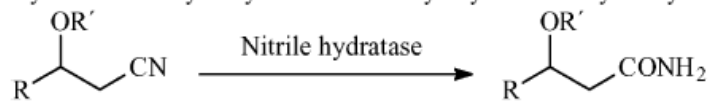

a $\quad$ b

\begin{tabular}{|c|c|c|c|c|c|c|c|c|}
\hline Entry & Substrate & $\mathrm{R}$ & $\mathrm{R}^{\prime}$ & $\begin{array}{l}\text { Reaction } \\
\text { time (min) }\end{array}$ & $\begin{array}{l}\text { Enzyme/substrate ratio } \\
\text { (U⿺辶a } / \mathrm{mmol} \text { substrate) }\end{array}$ & $\begin{array}{l}\text { Substrate } \\
\text { conversion (\%) }\end{array}$ & Product & $\begin{array}{l}\text { Isolated yield }{ }^{\mathrm{b}} \\
(\%)\end{array}$ \\
\hline 10 & $10 \mathbf{a}(15)$ & Phenyl & $\mathrm{H}$ & 60 & 10 & $>99$ & $10 b$ & 82 \\
\hline 11 & $11 \mathbf{a}(15)$ & tert-Butyl & $\mathrm{H}$ & 60 & 25 & $>99$ & $11 b$ & 91 \\
\hline 12 & $12 \mathbf{a}(10)$ & 2-Furyl & $\mathrm{H}$ & 60 & 20 & $>99$ & $11 b$ & 58 \\
\hline 13 & $13 \mathbf{a}(2.5)$ & Propyl & $\mathrm{Bz}$ & 180 & 130 & $>99$ & $13 b$ & 79 \\
\hline
\end{tabular}

a Activity determined with benzonitrile $(25 \mathrm{mM})$ as substrate.

${ }^{b}$ On $15-25 \mathrm{mg}$ scale. 
Table 4

Conversion of 3-oxo-3-phenylpropanenitrile (1a) and $(R, S)$-2-(1-hydroxyethyl)propenenitrile (5a) by cross-linked nitrile hydratase/amidase aggregates $(0.4 \mathrm{U} \mathrm{mL}-1$ reaction mixture)

\begin{tabular}{|c|c|c|c|c|c|c|}
\hline Entry & Substrate $(\mathrm{mM})$ & $\begin{array}{l}\text { Ammonium } \\
\text { sulfate (mM) }\end{array}$ & $\begin{array}{l}\text { Reaction } \\
\text { time (min) }\end{array}$ & $\begin{array}{l}\text { Nitrile conversion } \\
(\%)^{\mathrm{a}}\end{array}$ & $\begin{array}{l}\text { Amide } \\
\text { yield }(\%)^{\mathrm{a}}\end{array}$ & $\begin{array}{l}\text { Ratio of amide in } \\
\text { total product }(\%)^{\mathrm{a}}\end{array}$ \\
\hline 14 & $1 \mathbf{a}(10)$ & 0 & 180 & $>99$ & 3.2 & 3.2 \\
\hline 15 & & 360 & 180 & $>99$ & 75.3 & 75.3 \\
\hline 16 & & 800 & 180 & 71.3 & 65 & 86.9 \\
\hline 17 & 5a (10) & 0 & 180 & $>99$ & 42.9 & 42.9 \\
\hline 18 & & 360 & 180 & $>99$ & 66.9 & 66.9 \\
\hline 19 & & 800 & 180 & 92.3 & 81.8 & 88.6 \\
\hline
\end{tabular}

Note: The remainder of total product consisted of 3-oxo-3-phenylpropanoic acid (1d) and acetophenone (entries 14-16) or (R,S)-2-(1-hydroxyethyl)propenoic acid (5c, entries 17-19).

a Determined by HPLC.

phoric acid in water at a flow rate of $0.9 \mathrm{~mL} \mathrm{~min}^{-1}$. Enantiomers of $\mathbf{6 b}, \mathbf{7 a}, \mathbf{7 b}$ and $9 \mathbf{a}$ were separated using Chiralcel OD-H column (Daicel) with a mobile phase consisting of hexane: 2-propanol, 9:1 (v/v) at a flow rate of $0.8 \mathrm{~mL} \mathrm{~min}^{-1}$. Separation of enantiomers of 10a was performed using Chiral-AGP column $(5 \mu \mathrm{m}$ particles, $100 \mathrm{~mm} \times 4.0 \mathrm{~mm}$, ChromTech, Hägersten, Sweden) with a mobile phase consisting of $10 \mathrm{mM} \mathrm{Na-phosphate} \mathrm{buffer,} \mathrm{pH}$

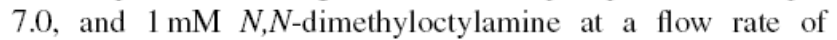
$0.9 \mathrm{~mL} \mathrm{~min}^{-1}$.

\subsection{Product isolation and identification}

Amides were extracted from the reaction mixtures with ethyl acetate at $\mathrm{pH} 8.5-9(1 \mathrm{M} \mathrm{KOH})$ or from the lyophilisates of the reaction mixtures with dry methanol (compounds 5b-6b). Compound $\mathbf{9 b}$ was purified by preparative HPLC using a Nucleosil $120-5, \mathrm{C}_{18}$ column $(5 \mu \mathrm{m}, 8 \mathrm{~mm} \times 250 \mathrm{~mm}$; Macherey-Nagel $)$ and a mobile phase consisting of $10 \%$ acetonitrile and $0.1 \%$ acetic acid in water at a flow rate of $1 \mathrm{~mL} \mathrm{~min}^{-1}$. The products were characterized by their ${ }^{1} \mathrm{H}$ and ${ }^{13} \mathrm{C}$ NMR spectra (recorded on a $400 \mathrm{MHz}$ spectrometer Varian UNITY Inova-400).

\subsection{Cloning and sequencing}

The DNA manipulation techniques and transformation of $R$. erythropolis were carried out as described previously [17]. To amplify the DNA fragment covering parts of the nitrile hydratase genes (coding for its $\alpha$ - and $\beta$-subunits) by PCR, the degenerated primers NHAF1 (GTGTGCT/ACG/TCTGTGTTC) and NHBR2 (TCGTGT/GAC/TTCCATCCAT) designed according to the conserved regions of the sequences of genes coding for Fe-type nitrile hydratases from several Rhodococcus strains were used: R. erythropolis AJ270 (GenBank accession no. AJ716152), R. erythropolis DSM43006 (AY223835), $R$. erythropolis ARG-AN024 (AY223830), R. erythropolis ANT-AN007 (AY223827), $R$. globerulus A-4 (AB105912), $R$. rhodochrous L (E03848), R. rhodochrous $\mathrm{H}$ (E03847) and Rhodococcus sp. N-771 (AB016078). Total DNA from $R$. erythropolis A4 was used as a template. The amplified fragment (about $0.3 \mathrm{~kb}$ ) was cloned in Escherichia coli into the $S m a \mathrm{I}$ site of the E. coli vector pK18mobsacB [18]. The resulting construct pNH343 was isolated from $E$. coli cells and introduced into $R$. erythropolis A4 by electrotransformation using the previously described protocol [17]. The regions flanking the cloned parts of nha1 and nha2 were isolated by the plasmid-rescue technique from the clones with the plasmid pNH343 (selected on kanamycin) integrated into the $R$. erythropolis A4 chromosome. The sequences of the genes nhal and nha 2 and the flanking regions were determined by primer walking using the ABI Prism 2100 sequencer (Perkin-Elmer). The resulting nucleotide sequence (1701 bp) was deposited in GenBank database under accession no. AM710613.

\section{Results and discussion}

\subsection{Biotransformations catalyzed by the semi-purified nitrile hydratase}

When using whole cells of $R$. erythropolis A4, the end products of nitriles examined in this study were mostly carboxylic acids. In some cases, careful monitoring of the reaction course enabled to obtain amides of reasonable purity (unpublished results). However, a semi-purified nitrile hydratase used in this work proved to be a biocatalyst of choice for the synthesis of pure amides from nitriles. The enzyme was partially purified in two chromatographic steps [6] and applied to transformation of nitriles 1a-13a (Tables 1-3). The enzyme was not very sensitive to steric hindrances imposed by branched and substituted nitriles. Only the most bulky nitriles 9a and 13a reacted sluggishly but the corresponding amides $\mathbf{9 b}$ and $\mathbf{1 3} \mathbf{b}$ (Table 2, entry 9 and Table 3, entry 13, respectively) could be obtained by either extending the reaction time and/or increasing enzyme/substrate ratio. 3-Oxonitriles 1a-4a (Table 1) also required high enzyme/substrate ratio for total conversion. This was probably caused by deactivation of the enzyme in presence of compounds containing reactive oxo groups. The conversion of all compounds except for $9 \mathbf{a}$ was nearly quantitative and the isolated yields of the corresponding amides were in general good to excellent.

The utility of the semi-purified enzyme was also demonstrated by the chemoselective transformation of cyano ester 13a. 
When ester groups were present in the substrate molecules, whole cells often gave deesterified products due to presence of esterases [1], which are ubiquitous in microorganisms. On the other hand, no ester hydrolysis was observed during the reaction catalyzed by the semi-purified nitrile hydratase (see Table 3 , entry 13). However, the sterically hindered nitrile required high enzyme/substrate ratio and extended reaction time for full conversion.

\subsection{Enantioselectivity of the nitrile hydratase}

The nitrile hydratase from $R$. erythropolis exhibited a good enantioselectivity towards several nitriles like 2-(4methoxyphenyl)propionitrile, 2-(6-methoxy-2-naphtyl)propionitrile [6], trans- $N$-(2-cyanocyclohexyl)benzamide and trans- $N$ (2-cyanocyclohexyl)-4-methylbenzenesulfonamide [19]. In this work, enantioselectivity of the nitrile hydratase was examined with substrates $6 \mathbf{a}, 7 \mathbf{a}, 9 \mathbf{a}$ and $10 \mathbf{a}$, as chiral separations of these nitriles or the corresponding amides were feasible using HPLC. The low $E(2.8)$ of the hydration of $(R, S)-2-(\alpha-$ hydroxybenzyl)propenenitrile (7a) was not surprising due to the distant position of the stereogenic carbon atom from the reactive cyano group. Previously, low $E$-values were reported for the hydrolysis of this compound by whole cells of Rhodococcus sp., while the hydration step was found to be non-selective [20]. Addition of cosolvents $(5-20 \%(\mathrm{v} / \mathrm{v})$ methanol or pristane) did not cause any significant change of enantioselectivity (data not shown). The enantioselectivity of the nitrile hydratase for nitrile 6a was similar $(E=2.7)$. The hydration of nitriles 9a and 10a was non-selective.

\subsection{Biotransformations using cross-linked nitrile hydratase aggregates}

Recently we observed a strong inhibitory effect of ammonium ions on amidase activity of cell-free extracts from R. erythropolis (5\% residual activity in the presence of $800 \mathrm{M}$ ammonium sulfate [7]). This finding suggested that addition of ammonium ions may improve the purity of amides formed by crude nitrile hydratase preparations, provided the nitrile hydratase remains active at concentrations, which suppress the amidase activity. The effect of ammonium ions on both enzymes was examined using a cell-free extract in the form of cross-linked enzyme aggregates (CLEAs).

Approximately $88 \%$ of the nitrile hydratase activity was recovered after immobilization of the cell-free extract in CLEAs, when using ammonium sulfate as precipitant. The use of other precipitants resulted in complete deactivation of the enzyme. Comparison of glutaraldehyde and dextran polyaldehyde as cross-linking agents showed that only the latter compound was suitable for nitrile hydratase, while the former one was detrimental to the enzyme activity (data not shown). Recently, a similar effect of glutaraldehyde was observed with nitrilase [10]. The nitrile hydratase in CLEAs was stabilized by immobilization. The immobilized enzyme retained $77 \%, 46 \%$ and $25 \%$ of its initial activity after 1,4 and $10 \mathrm{~h}$, respectively, while the cell-free extract was less stable with $66 \%$ and $27 \%$ of residual activity

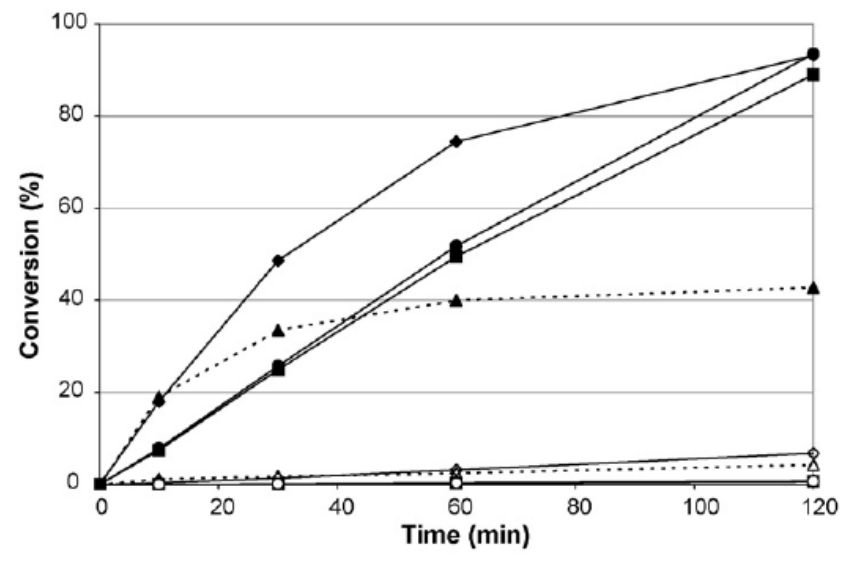

Fig. 1. Biotransformation of benzonitrile $(25 \mathrm{mM})$ into benzamide ( $\mathrm{mM}$; closed symbols) and benzoic acid (mM; open symbols) by cell-free extract in absence of ammonium sulfate (triangles, broken line) and by cross-linked enzyme aggregates in absence (diamonds) or presence of $360 \mathrm{mM}$ (circles) and $800 \mathrm{mM}$ (squares) ammonium sulfate. The reaction mixture contained $0.5 \mathrm{U}$ of nitrile hydratase $\mathrm{mL}^{-1}$. See Section 2 for details.

after 1 and $4 \mathrm{~h}$, respectively. Comparison of benzonitrile conversion by cell-free extract and CLEAs also indicated a slower deactivation of the latter biocatalyst (see Fig. 1). Amidase activity was also present in CLEAs at approximately $77 \%$ of its initial activity. The selective inhibition of amidase was demonstrated in a CLEA-catalyzed conversion of benzonitrile (see Fig. 1). In absence of ammonium sulfate, the ratio of benzoic acid in the total product was approximately $6 \%$. The addition of ammonium sulfate ( 360 or $800 \mathrm{mM}$ ) decreased this ratio by $8-10$ times, the effect of both concentrations of the salt being similar. Furthermore, ammonium sulfate exhibited a stabilizing effect on the nitrile hydratase activity in CLEAs. In presence of any of the examined concentrations of ammonium sulfate, the reaction rate was almost stable during $120 \mathrm{~min}$, while it slowed down after $30 \mathrm{~min}$ in the reaction mixture without ammonium sulfate. Thus, despite a lower initial reaction rate (by about one half), the biotransformations carried out in presence of ammonium sulfate afforded comparable benzamide yields as the control without ammonium sulfate.

Previously it was reported that whole cells of $R$. rhodochrous produced significant amounts of 3-oxo-3-phenylpropanoic acid (1d) together with acetophenone (product of decarboxylation of 1d) from nitrile 1a, unless the microorganism was grown in the presence of diethylphosphoramidate [4]. The same reaction pattern was observed for the CLEA-catalyzed reaction in buffer without ammonium sulfate (see Table 4, entry 14). However, in presence of $360 \mathrm{mM}$ ammonium sulfate the ratio of amide in total product was $75 \%$ after full conversion of $\mathbf{1 a}$ (see Table 4 , entry 15). At $800 \mathrm{mM}$ ammonium sulfate, the rate of nitrile hydration decreased and total conversion was not achieved after $180 \mathrm{~min}$. On the other hand, the purity of the amide was the highest, total product consisting of $87 \%$ amide (see Table 4 , entry 16). Similar effects of ammonium sulfate were observed for the transformation of $(R, S)$-2-(1-hydroxyethyl)propenenitrile (5a) by CLEAs (see Table 4, entries 17-19). The amide ratio in the total product 
was $43 \%$ in absence of ammonium sulfate. At $360 \mathrm{mM}$ ammonium sulfate acid formation was reduced by almost one half. The best purity of the amide was achieved at $800 \mathrm{mM}$, when the total product consisted of $89 \%$ amide. The above examples illustrated the utility of ammonium sulfate as an amidase inhibitor, which enabled to control the course of the reactions to give the desired products.

\subsection{Sequence analysis of the nitrile hydratase genes}

Previously, we determined the N-terminal sequences of both subunits of the nitrile hydratase from $R$. erythropolis A4 [6] and stated that they were identical to those of the bestcharacterized nitrile hydratases from Rhodococcus sp. N-771 [21] and Rhodococcus sp. R 312 (formerly Brevibacterium sp. $R$ 312) [22]. Therefore, different substrate specificities of the nitrile hydratase studied by us, on one hand, and those of strains N-771 and R 312, on the other hand, were surprising (regarding, in particular, a high activity of the enzyme from strain A4 towards aromatic nitriles [6]). To shed more light on the elutionary relationships between the nitrile hydratase from strain A4, which showed a very broad substrate specificity (as shown herein and previously, e.g. [6,15,19,23]), and the nitrile hydratases from other strains, the genes coding for $\alpha$ - and $\beta$-subunits of nitrile hydratase were cloned and their nucleotide sequences determined. The DNA fragment (1286 nt) covering the genes nhal and nha 2 and their intergenic region (26 nt) from $R$. erythropolis A4 differs by $10 \mathrm{nt}$ from the most similar homologous sequence from $R$. erythropolis 870 -AN019 (GenBank accession no. AY223829) [24] according to the similarity search in GenBank database. The deduced $R$. erythropolis A4 polypeptides Nha1 ( $\alpha$-subunit) and Nha2 ( $\beta$-subunit) showed $100 \%$ aa identity with the deduced aa sequences of the nitrile hydratase subunits from three strains of $R$. erythropolis (67-BEN001, ANT-AN007 and ARG-AN025 [24] and with a sequence from the strain $R$. globerulus A-4 [25]. Some data on substrate specificity are available for strain 67-BEN001, which accepts aliphatic (di)nitriles, benzonitrile and 3-cyanopyridine [26].

All deduced aa sequences of other nitrile hydratases from Rhodococcus strains, whose substrate specificities were studied (strains N-774, N-771, AJ270 and R312), are highly similar to each other [24] and differ in the same six aa from $R$. erythropolis A4-deduced sequence. Considering the high degree of aa identity, similar substrate specificities of these enzymes could be expected. However, different substrate specificities of nitrile hydratases from Rhodococcus sp. (formerly Brevibacterium sp.) R312 [27] and from R. erythropolis A4 [6] have been described. The use of enzymes of a different purity or different experimental conditions could be responsible for the observed differences. Nevertheless, it is still possible that a few amino acid substitutions could modify the substrate specificity. Other hypothesis suggests that the primary structure of the enzyme affects its quarternary structure (e.g. dimers versus tetramers) [22]. In turn, quarternary structure of the enzyme could influence its catalytic properties. Reasons for the variations in the enzyme properties still deserve further investigation.

\section{Conclusions}

We searched for biocatalysts suitable for the hydration of nitriles into the corresponding amides. The semi-purified nitrile hydratase from $R$. erythropolis A4 accepted a broad range of branched and substituted nitriles and proved to be utilizable for the preparative biotransformations of these compounds into amides as sole products. A benefit of this approach is the simple work-up of the reaction mixture containing very small amounts of biological material $\left(<0.03 \mathrm{mg}\right.$ of protein $\left.\mathrm{mL}^{-1}\right)$ and nearly no residual substrate or by-product. Therefore, extraction with an organic solvent was sufficient to isolate the amides in most cases. This method proved useful for enzymatic synthesis of several important types of amides known as versatile intermediates for a large number of natural compounds and products with pharmaceutical impact like 3-oxoamides [4], 3- or 4-hydroxylated 2-methyleneamides [13] and 3-hydroxyamides [28].

Cross-linking of aggregates of the crude nitrile hydratase with dextran polyaldehyde provided another enzyme formulation suitable for the transformation of nitriles into amides. Using this biocatalyst, amides could be obtained as major products, when the reaction proceeded in presence of a selective amidase inhibitor, ammonium sulfate $(360-800 \mathrm{mM})$. Alternatively, the reaction conditions can be adjusted to favour carboxylic acid formation, as amidase also retained its activity in cross-linked enzyme aggregates.

Nitrile hydratases seem to be highly conserved in evolution. From the highly similar nitrile hydratases from rhodococci, the enzyme studied by us belongs to a few ones for that a large number of substrates was reported.

\section{Acknowledgements}

Financial support through projects ESF COST D25/0002/02 (STSM from David Kubáč from Institute of Microbiology Prague to TU Delft), 203/05/2267 (Czech Science Foundation), D10-CZ25/06-07 (DAAD, Academy of Sciences of the Czech Republic), LC06010 and OC 171, D-25 (Ministry of Education, Czech Republic) and the institutional research concept AV0Z50200510 (Institute of Microbiology) is gratefully acknowledged. We also wish to thank Prof. V. Gotor and Dr. R. Liz (Univ. Oviedo, Spain) for their generous gift of substrates 1a-4a and 10a-13a and advice on their synthesis, to Dr. F. van Rantwijk (TU Delft, The Netherlands) for advice on CLEA preparation, to Dr. V. Přikrylová (Institute of Microbiology, Prague) for sample purification by preparative HPLC and to Mrs. J. Horová (Institute of Microbiology, Prague) for her excellent technical assistance.

\section{Appendix A. Supplementary data}

Supplementary data associated with this article can be found, in the online version, at doi:10.1016/j.molcatb.2007.09.007.

\section{References}

[1] L. Martínková, V. Mylerová, Curr. Org. Chem. 7 (2003) 1279. 
[2] M. Kashiwagi, K.-I. Fuhshuku, T. Sugai, J. Mol. Catal. B: Enzym. 29 (2004) 249.

[3] R. Bauer, B. Hirrlinger, N. Layh, A. Stolz, H.-J. Knackmuss, Appl. Microbiol. Biotechnol. 42 (1994) 1.

[4] V. Gotor, R. Liz, A.M. Testera, Tetrahedron 60 (2004) 607.

[5] M. Cantarella, L. Cantarella, A. Gallifuoco, A. Spera, Enzyme Microb. Technol. 38 (2006) 126.

[6] I. Přepechalová, L. Martínková, A. Stolz, M. Ovesná, K. Bezouška, J. Kopecký, V. Křen, Appl. Microbiol. Biotechnol. 55 (2001) 150.

[7] V. Vejvoda, O. Kaplan, D. Kubáx, V. Křen, L. Martínková, Biocatal. Biotransform. 24 (2006) 414.

[8] L.Q. Cao, F. van Rantwijk, R.A. Sheldon, Org. Lett. 2 (2000) 1361.

[9] R. Schoevaart, M.W. Wolbers, M. Golubovic, M. Ottens, A.P.G. Kieboom, F. van Rantwijk, L.A.M. van der Wielen, R.A. Sheldon, Biotechnol. Bioeng. 87 (2004) 754.

[10] C. Mateo, J.M. Palomo, L.M. van Langen, F. van Rantwijk, R.A. Sheldon, Biotechnol. Bioeng. 86 (2004) 273.

[11] R.L. Rajender, R.K. Rama, Org. Prep. Proced. Int. 32 (2000) 185.

[12] J.S. Hill, N.S. Isaac, J. Chem. Res. Miniprint 10 (1988) 2641.

[13] D. Crestia, C. Guérard, H. Veschambre, L. Hecquet, C. Demuynck, J. Bolte, Tetrahedron: Asymmetry 12 (2001) 869.

[14] C.J. Eby, C.R. Hauser, J. Am. Chem. Soc. 79 (1957) 723.

[15] V. Vejvoda, O. Šveda, O. Kaplan, V. Př́ikrylová, V. Eliš́ková, M. Himl, D. Kubác, H. Pelantová, M. Kuzma, V. Kr̛en, L. Martínková, Biotechnol. Lett. 29 (2007) 1119.
[16] M.J. DiGeronimo, A.D. Antoine, Appl. Environ. Microbiol. 31 (1976) 900.

[17] M. Veselý, M. Pátek, J. Nešvera, A. Čejková, J. Masák, V. Jirků, Appl. Microbiol. Biotechnol. 61 (2003) 523.

[18] A. Schäfer, A. Tauch, W. Jäger, J. Kalinowski, G. Thierbach, A. Pühler, Gene 145 (1994) 69.

[19] M. Winkler, L. Martínková, A.C. Knall, S. Krahulec, N. Klempier, Tetrahedron 61 (2005) 4249.

[20] M.-X. Wang, Y. Wu, Org. Biomol. Chem. 1 (2003) 535

[21] M. Nakasako, M. Odaka, M. Yohda, N. Dohmae, K. Takio, N. Kamiya, I. Endo, Biochemistry 38 (1999) 9887.

[22] W.J. Huang, J. Jia, J. Cummings, M. Nelson, G. Schneider, Y. Lindquist, Structure 5 (1997) 691.

[23] L. Martínková, N. Klempier, M. Preiml, M. Ovesná, M. Kuzma, V. Mylerová, V. Křen, Can. J. Chem. 80 (2002) 724.

[24] P.F.B. Brandao, J.P. Clapp, A.T. Bull, Appl. Environ. Microbiol. 69 (2003) 5754.

[25] S.X. Xie, Y. Kato, Y. Asano, Biosci. Biotechnol. Biochem. 65 (2001) 2666.

[26] S.C. Heald, P.F.B. Brandao, R. Hardicre, A.T. Bull, Antonie van Leeuwenhoek 80 (2001) 169

[27] T. Nagasawa, K. Ryuno, H. Yamada, Biochem. Biophys. Res. Commun. 139 (1986) 1305

[28] Z.-L. Wu, Z.-Y. Li, J. Mol. Catal. B: Enzym. 22 (2003) 105. 